\title{
Regularities in the distribution of granulometric composition of tuff while crushing
}

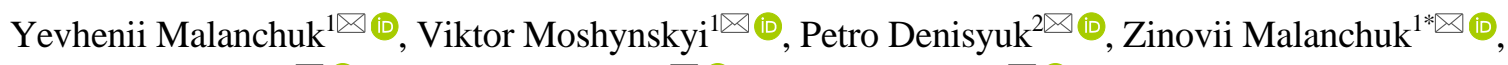

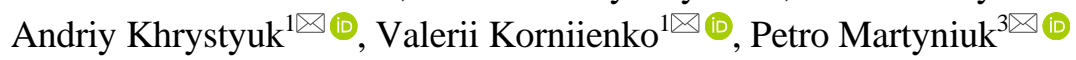 \\ ${ }^{1}$ National University of Water and Environmental Engineering, Rivne, 33028, Ukraine \\ ${ }^{2}$ Educational and Scientific Institute of Law, Rivne, 33028, Ukraine \\ ${ }^{3}$ Educational and Scientific Institute of Automation, Cybernetics and Computer Engineering, 33028, Ukraine \\ *Corresponding author: e-mail malanchykzr@ukr.net, tel. +380507774231
}

\begin{abstract}
Purpose is to analyze distribution of granulometric composition of tuff as well as ultimate composition and identify dependence of its softening in the process of water saturation based upon a set of experiments to assess raw materials importance of the mineral.

Methods. Laboratory experiments were carried out to determine ultimate composition of tuff extracted from different open pits of the region. Methods of mathematical statistics were applied to derive analytical dependences describing the tuff softening in the process of water saturation. The dependences denote logarithmic nature of the saturation increase along with the increase in the sample weight.

Findings. It has been determined that tuff is a valuable mineral rather than basalt extraction waste. Thus, tuff needs both mining and complex approaches for processing and extracting of useful metals and silicates. Analytical dependences of tuff softening during water saturation have been defined. The dependences denote logarithmic nature of the saturation increase based upon a sample weight increment. Magnetic susceptibility of tuff, turned on magnetic field induction, has been identified. Dependences of distribution of technological indices (i.e. product yield, copper content and yield) in terms of granulometric-size class have been identified; the basic factors for crushing process have been determined; and regression dependences of grinder efficiency upon the input factors have been derived. Regression model of a crushing process of a general technological scheme of ore processing has been obtained involving the initial fragmentation using a jaw crusher, and additional fragmentation (i.e. reduction) using a sizer.
\end{abstract}

Originality. It has been determined that magnetic susceptible tuff share is $49 \%$ of the sample weight; the remaining part is a silicate share. Logarithmic nature of the analytical softening dependences while water saturating has been identified. The above-mentioned denotes the increased saturation along with the increase in a sample weight.

Practical implications. The definition of tuff ultimate composition as well as analytical softening dependences in the process of water saturation makes it possible to calculate the required water consumption.

Keywords: tuff, basalt, softening, water saturation, silicate, magnetic susceptibility, ultimate composition, crushing

\section{Introduction}

The reserves of tuff raw materials in Rivne and Volyn Regions help perform their lasting commercial extraction. First of all, they attract owing to their accessibility as well as wide possibilities for use. Availability of diverse microelement composition makes it possible to carry out research concerning complex industrial tuff processing; more detailed studies of their characteristics; and improvement of mining methods and application area widening on this basis [1]-[3]. Practices of tuff use by various industries and agriculture support the efficiency of their application while increasing the interest of their extraction [4]-[7]. Hence, it is required to improve techniques of its processing, and bringing into a state of the end product in accordance with the terms and conditions of use.

Rich mineral tuff composition; available microelements of rare metals; high content of iron, titanium, and native copper within the region tuff stipulate the necessity of their complex processing. The first stage is rock mass preparation to extract valuable components [8]. At the same time, it should be mentioned that study of geomechanical production

Received: 11 June 2020. Accepted: 9 February 2021. Available online: 5 March 2021

(C) 2021. Ye. Malanchuk et al.

Published by the Dnipro University of Technology on behalf of Mining of Mineral Deposits. ISSN 2415-3443 (Online) | ISSN 2415-3435 (Print)

This is an Open Access article distributed under the terms of the Creative Commons Attribution License (http://creativecommons.org/licenses/by/4.0/),

which permits unrestricted reuse, distribution, and reproduction in any medium, provided the original work is properly cited. 
processes in the context of specific mining and geological conditions is an important component as well [9], [10]. In this case, computer modeling [11], [12]; equivalent material mo-deling [13], [14]; and experimental field studies [15]-[17] are in wide use. It goes without saying that special emphasis is placed on the environmental impact [18]-[21].

Tuff types are distinguished easily by eye. They may be brown, chestnut-brown, or greenish-gray in open pit benches or in dumps depending upon metal oxides within them. Tuff is monolithic and unstable in the solid being slably fine- or coarse-granulometric in dumps. Principally, tuff is of acinose texture in the form of slags consisting of various basalts, volcanic glass, minerals, pyroxene, granulometrics of quartz and feldspar. Generally, such components are cemented by zeolites, smectites, and analcite; rarely, the process is performed with the help of calcite and chalcedony [22]-[26].
Papers [27], [28] studied thoroughly and published mineral composition of tuff in Rivne Region. Mineralogical analysis has helped identify that zeolite content in the tuff of Polytsk open pit is as follows: almost $43 \%$ of smectites and 16 to $32 \%$ of iron-rich fine materials. Roentgen analysis as well as thermal one has made it possible to determine that the tuff involves $65 \%$ of smectites and up to $28 \%$ of analcite. The results show that in terms of petrogenic mineral content, the tuff in Rivne Region has been modified. It is represented by zeolitesmectite rocks which experienced significant secondary transformations as well as hydrothermal mineralization [29], [30].

The research helps use the tuff purposefully and efficiently. Data, concerning the average microelement content in tuff from three deposits, are of specific interest. Table 1 demonstrates average microelement content within three open pits in Rivne Region, its correspondence to clarkes as well as to the thresh limit value (TLV) in the ground.

Table 1. Average microelement content in tuff, $10^{-4} \%$

\begin{tabular}{|c|c|c|c|c|c|c|c|c|c|c|c|c|c|c|}
\hline Elements & $\mathrm{P}$ & $\mathrm{Pb}$ & $\mathrm{Ba}$ & Mo & $\mathrm{Sn}$ & $\mathrm{Cu}$ & $\mathrm{Zn}$ & $\mathrm{Ni}$ & $\mathrm{Zr}$ & Co & $\mathrm{Cr}$ & $\mathrm{V}$ & $\mathrm{Mn}$ & $\mathrm{Ti}$ \\
\hline \multicolumn{15}{|c|}{ Rafalivka open pit } \\
\hline Average value & 670 & 5 & 350 & 0.8 & 5 & 103 & 46 & $\begin{array}{c}\text { Studies } \\
35\end{array}$ & 140 & 31 & 47 & 116 & 1240 & 5480 \\
\hline Clarkes & 1500 & 6 & 330 & 1.5 & 6 & 87 & 105 & 130 & 110 & 48 & 170 & 250 & 1200 & 8000 \\
\hline TLV & - & 30 & - & - & - & 100 & 100 & 100 & - & - & 100 & 150 & 1500 & - \\
\hline \multicolumn{15}{|c|}{ Berestovets open pit } \\
\hline Average value & 600 & 6 & 8000 & 1.0 & 2 & 300 & 40 & 25 & 200 & 25 & 30 & 400 & 600 & 6000 \\
\hline Clarkes & 1500 & 6 & 330 & 1.5 & 6 & 87 & 87 & 130 & 110 & 48 & 170 & 250 & 1200 & 8000 \\
\hline TLV & - & 30 & - & - & - & 100 & 100 & 100 & - & - & 100 & 150 & 1500 & - \\
\hline \multicolumn{15}{|c|}{ Tashkivka open pit } \\
\hline Average value & 150 & 19 & 75 & 104 & 32 & 168 & 23 & 118 & 3 & 320 & 2 & 0,1 & - & - \\
\hline Clarkes & 170 & 130 & 87 & 105 & 60 & 470 & 21 & 6 & 4 & 330 & 1.5 & 2 & - & - \\
\hline TLV & 100 & 100 & 100 & 100 & - & - & - & 30 & - & - & - & 2 & - & - \\
\hline
\end{tabular}

Studies of the research to identify microelement content of the tuff demonstrate the following: the microelements cannot be considered as basalt waste being instead valuable mineral raw materials requiring mining as well as development of the integrated approach for processing to extract precious metals and silicates [31], [32]. Specific attention is paid to a magnetic method determining basic characteristics of the raw materials [33]-[35].

Previous studies of the tuff from the viewpoint of its industrial use, started by geologists from Rivne mining part, and experts from the Institute of Geotechnical mechanics named by N. Poliakov of the National Academy of Sciences of Ukraine in association with the National University of Water and Environmental Engineering (city of Rivne) denote high content of native copper $(0.7 \%)$; and unexpectedly high content of magnetic susceptible material (54\%). Results of spectral analysis identify up to $50 \%$ content of iron, and up to $4 \%$ of titanium. The research results, shown in Table 1 , support the tuff value as raw material for mining industry and metallurgical industry.

The majority of the tuff components are useful from the commercial viewpoint. According to the requirements of complex application of raw materials, schematic of its processing method should take into consideration probabilistic division into the required number of monomineral concentrates extracted from tuff rock mass [36]-[38]. Even in terms of the basic components (i.e. native copper, iron, and titanium), being interesting commercially, processing of waste tuff is profitable; environmentally friendly; and expedient socially taking into consideration its occurrence as well as future development of the region [39], [40].

Singularity of tuff is as follows: freshly mined, it is wellhardened being a half rock. However, after long-term moisture effect it breaks up easily forming a loose mixture [41]-[43]. The rock decomposition results in the formation of tuff granules which grading corresponds to sand; particle size is 3.00 down to $1.00 \mathrm{~mm}$. Loose density of the fragmented tuff is within $0.96-1.22 \cdot 10^{3} \mathrm{~kg} / \mathrm{m}^{3}$; specific surface is $120-150 \mathrm{~m}^{2} / \mathrm{kg}$. Total porosity of the dispersed tuff material achieves $30 \%$; water regain is $30 \%$ (if coagulant is available, the regain is $62 \%$ ); moisture absorption in terms of weigh is almost $18 \%$; and moisture absorption in terms of volume is 33\% [44], [45].

In Berestovets open pit, tuff is of two types differing in their compositions. Claystone-like aleurite tuff with 1-5 m thickness underlays a basalt layer. Vertically, more granular psammitic and psephitic tuff occurs below. Aleurite tuff contains almost $65 \%$ of smectites, hydrous ferric oxides as well as high concentration of barium, vanadium, copper, and zirconium.

Up to now, tuff of Tashkivka deposits has been studied to the fullest extent possible geologically and commercially. They have high saponite content (up to 80\%) thus demonstrating both sorption and cation-exchange characteristics. High magnesia content ( $\mathrm{MgO}$ is up to $11.6 \%$ ) as well as high content of such microelements as copper, chrome, and zinc is typical for the tuff. Nonavailability of arsenic, mercury, and selenium, being environmentally hazardous elements, is quite an important factor (Table 1). 
It should be noted that even the initial stages of tuff component studies (while developing methods of its pretreatment and preparation) have helped determine certain features. Among other things, it concerns copper spots which can be identified visually in samples in the form of either granular or thin films. In the process of crushing, grinding, and screening, the films are destructed down to less than $50 \mu \mathrm{m}$ shots complicating their extraction by separators. Compounds of iron and other metals are represented by means of larger particles being removed from the total mass with the help of magnetic separation. However, availability of numerous bindings with the tuff silicate component should be mentioned. Generally, the component is represented by silicon and calcium; it is separated while regrinding or melting [46].

The research objective is to identify regularities of changes in granulometric composition of zeolite-smectite tuff of open-pit and borehole production while crushing and grinding taking into consideration lumpiness.

\section{Methods}

The paper considers two mining techniques: well hydraulic production and open-pit one [47]-[50]. The most fragmentaulic tuff mass results from open-pit production if tuff, extracted by means of blasting in the process of basalt bench mining using explosive method, is of less lumpiness to compare with basalt or lava-breccia. However, to make a decision, concerning its further processing, it is required to analyze the tuff granulometric composition both in a dump and while crushing. The studies were carried out using zeolitesmectite tuff from Rafalivka basalt open pit by means of $1 \mathrm{~m}^{3}$ dump tuff mass dispersion with the help of a vibratory screen both before crushing and after it. In this context, the crushed tuff was studied using several moistening cycles. It has been determined that the largest lumps within the crushed dumped tuff are $250-300 \mathrm{~m}$; their content is $2-3 \%$. After crushing, maximum lumps are $100-150 \mathrm{~mm}$; their content was not more than $5 \%$.

The research involved experiments for the analysis of site-collected tuff samples both under laboratory conditions and under production-line ones to select a schematic of tuff mining and processing. Mathematical statistics methods to identify the basic factors influencing the analyzed process have been applied to process the research results and obtain mathematical dependences.

\section{Results and discussion}

Ore preparation and tuff extraction from a basalt open pit dump and wells originates the necessity to study granulometric composition of the tuff to select equipment and perform further processing of the mineral. Separation into fine and very fine grades is one of the important procedures of tuff processing and preparation for washing. It has been determined that excessive tuff grinding affects negatively the quality of further extraction of useful components.

Analysis of tuff granulometric composition after well hydraulic production shows differences in its characteristics depending upon crushing; moreover, the differences become more visible to compare with open-pit mining. Table 2 demonstrates size distribution $Q_{k}(\mathrm{~mm})$ of the uncrushed tuff of open-pit and well production. Table 3 demonstrates size distribution of the crushed tuff. As for the well hydraulic production, granulometric composition was determined in terms of $1 \mathrm{~m}^{3}$ of the alluviated tuff within the alluviation map.
Table 2. Granulometric tuff composition before crushing

\begin{tabular}{lcccccc}
\hline \multicolumn{7}{c}{ Open-pit production } \\
\hline Size, $Q_{k}, \mathrm{~mm}$ & 350 & 130 & 60 & 50 & 40 & 30 \\
Quantity, $K, \%$ & 3 & 9 & 30 & 48 & 70 & 90 \\
\hline \multicolumn{7}{c}{ Well production } \\
\hline Size, $Q_{k}, \mathrm{~mm}$ & 40 & 20 & 15 & 10 & 7 & 3 \\
Quantity, $K, \%$ & 5 & 15 & 27 & 50 & 70 & 90 \\
\hline
\end{tabular}

Table 3. Granulometric tuff composition after crushing

\begin{tabular}{lcccccc}
\hline \multicolumn{7}{c}{ Open-pit production } \\
\hline Size, $Q_{k}, \mathrm{~mm}$ & 200 & 60 & 35 & 30 & 20 & 10 \\
Quantity, $K, \%$ & 10 & 23 & 40 & 50 & 70 & 90 \\
\hline \multicolumn{7}{c}{ Well production } \\
\hline Size, $Q_{k}, \mathrm{~mm}$ & 20 & 12 & 7 & 5 & 4 & 2 \\
Quantity, $K, \%$ & 3 & 25 & 45 & 60 & 70 & 90 \\
\hline
\end{tabular}

Relying upon the results, a roll crusher with flexible roll spacings is recommended for further tuff processing. Figure 1 shows the findings in the form of dependence of the fragmented crushed tuff $\left(\gamma_{n}, \mathrm{~mm}\right)$ quantity $\left(K_{n}, \%\right)$ upon the roll crusher spacing regulated within $\Delta=3-10 \mathrm{~mm}$.

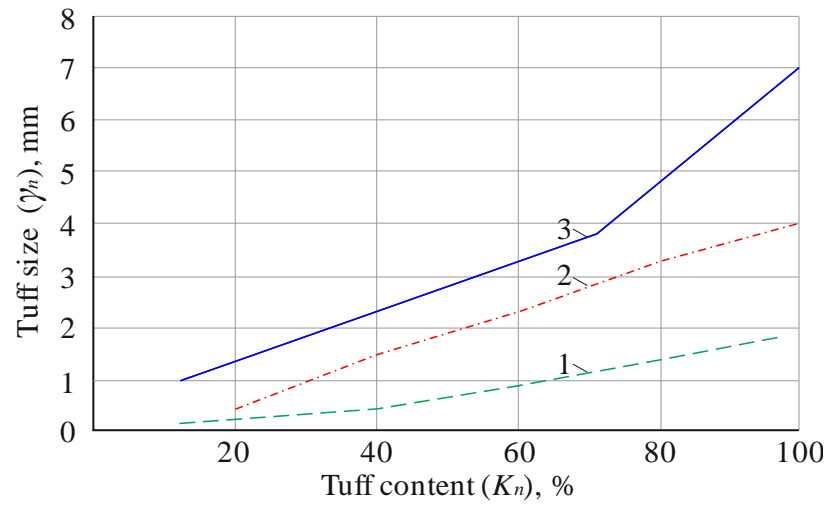

Figure 1. Dependence of the fragmented crushed tuff size upon the crusher rollers: $1-3 \mathrm{~mm} ; 2-6 \mathrm{~mm} ; 3-10 \mathrm{~mm}$

Figure 2 demonstrates the findings in the form of dependence of the fragmented uncrushed tuff $\left(\gamma_{n}, \mathrm{~mm}\right)$ quantity $\left(K_{n}\right.$, $\%$ ) upon the roll crusher spacing regulated within $\Delta=3-10 \mathrm{~mm}$.

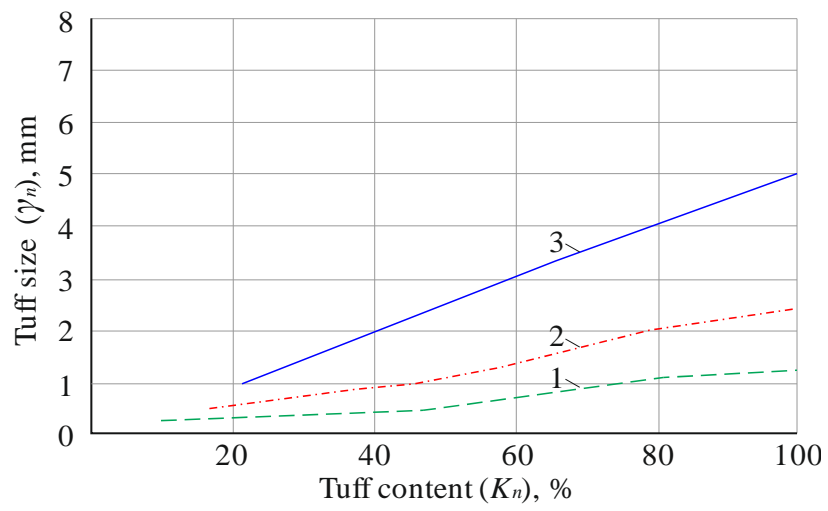

Figure 2. Dependence of the fragmented uncrushed tuff size upon the crusher rollers: $1-3 \mathrm{~mm} ; 2-6 \mathrm{~mm} ; 3-10 \mathrm{~mm}$

Analysis of granulometric tuff composition of the openpit production and the well one helps conclude that it is possible to apply a roll crusher with 2-3 $\mathrm{mm}$ spacing between rollers for tuff re-crushing, and its preparation for a very fine grade. 
Over the research years, Rafalivka open pit tuff was analyzed spectrally. The comparative results of such a express analysis, shown in Table 4, denote relatively stable content of copper, iron, and titanium in the tuff. The abovementioned excludes fundamental changes in their processing techniques during a long-time period.

\section{Table 4. Results of the spectral express analysis}

\begin{tabular}{lccccc}
\hline \multirow{3}{*}{ Element } & \multicolumn{5}{c}{ Year-based content of the elements within tuff } \\
& samples in & the context of Rafalivka open pit, \% \\
\cline { 2 - 6 } & 2005 & 2006 & 2007 & 2008 & 2009 \\
\hline Aluminium & 0.00 & 0.07 & 0.07 & 0.03 & 0.07 \\
Silicon & 30.92 & 32.10 & 31.60 & 32.00 & 32.50 \\
Phosphorus & 0.10 & 0.15 & 0.15 & 0.15 & 0.07 \\
Lead & 0.50 & 0.30 & 0.50 & 0.30 & 0.30 \\
Potassium & 1.28 & 1.41 & 1.51 & 1.52 & 1.60 \\
Calcium & 6.34 & 9.80 & 10.80 & 12.50 & 12.10 \\
Titanium & 3.98 & 7.00 & 2.80 & 1.80 & 2.60 \\
Chrome & 0.20 & 0.30 & 0.10 & 0.07 & 0.07 \\
Manganese & 0.81 & 0.05 & 0.07 & 0.15 & 0.15 \\
Iron & 52.06 & 48.10 & 51.30 & 50.80 & 49.90 \\
Nickel & 0.22 & 0.07 & 0.05 & 0.09 & 0.05 \\
Copper & 0.70 & 0.20 & 0.60 & 0.40 & 0.45 \\
Zink & 0.06 & 0.05 & 0.01 & 0.01 & 0.01 \\
Strontium & 0.11 & 0.01 & 0.01 & 0.01 & 0.01 \\
Zirconium & 0.28 & 0.20 & 0.15 & 0.10 & 0.15 \\
Cobalt & 0.02 & 0.01 & 0.05 & 0.05 & 0.03 \\
\hline
\end{tabular}

Efficient method of tuff extraction from iron and native copper should involve a procedure of the mineral crushing down to a size providing maximum separation of a mineral part from a silicate one. Fine tuff analysis within a magnetic field has demonstrated high magnetic sensitivity of the former, making it possible to separate titanium magnetic share from the prepared sizing. Native copper inclusions are of a point nature or a film one (at a micron level). Thus, extraction should involve such a size being adequate for separation. To solve the problem, crushing studies were carried out using ball-bearing mills, vibration mills, roller mills, and drum ones. It has been identified that three of the abovementioned mills demonstrate significant regrinding of diamagnetic copper-bearing tuff component increasing its losses while extracting. In terms of certain crushing modes, roller mills as well drum ones produce the crushed mass in the form of small flakes containing silicate share of tuff (volcanic glass, calcium, silica, and small copper nuggets). Production of the crushed mass complicates the development of a method for further copper extraction.

Intra-roll conical vibration mill by the Institute of Geotechnical Mechanics named by N. Poliakov of the National Academy of Sciences of Ukraine has shown positive results. The mechanism fragments rock, using repetitive compressive deformation with shear rather than simple crushing. In this context, silicate share is flaked off from copper nuggets, rolling into balls, ellipsoids or small sticks, making it possible to separate them later by means of grading with the help of a vibratory screen [51].

Taking into consideration significant titanium magnetite content in tuff (up to $47 \%$ ) as well as its high magnetic sensitivity, ore mass separation using a sizer becomes efficient if grinding coarseness is $1-3 \mathrm{~mm}$. However, in addition to a silicate share, the grade contains considerable amount of fine native copper. Hence, from the viewpoint of maximum extraction efficiency (to $0.7 \%$ ), tuff crushing should be continued up to its adequate largeness using no regrinding to avoid the increased metal losses. Maximum titanium magnetite extraction by means of magnetic separation and native copper extraction by means of electric separation are the rational grade criteria.

Hence, the research has demonstrated that fine grinding is quite a sufficient procedure for tuff processing at a stage of ore preparation for its further complex use. For instance, roll mills are applicable for this purpose to perform extra grinding down to adequate largeness, which would satisfy processes of maximum extraction of titanium magnetite as well as native copper.

Table 5 explains findings concerning process parameters of crushability and copper content in terms of three size grades at the initial stage of ore preparation starting from crushing with the help of a jaw breaker and a roll mill. Following specifications are used: $\gamma$ is size yield; $\boldsymbol{\beta}$ and $\varepsilon$ are copper content and yield respectively.

Table 5. Process parameters of rock crushing at Rafalivka open pit

\begin{tabular}{|c|c|c|c|c|c|c|c|c|c|}
\hline \multirow{2}{*}{$\begin{array}{l}\text { Size grade, } \\
\mathrm{mm}\end{array}$} & \multicolumn{3}{|c|}{ Basalt } & \multicolumn{3}{|c|}{ Lava-breccia } & \multicolumn{3}{|c|}{ Tuff } \\
\hline & $\gamma, \%$ & $\beta, \%$ & $\varepsilon, \%$ & $\gamma, \%$ & $\beta, \%$ & $\varepsilon, \%$ & $\gamma, \%$ & $\beta, \%$ & $\varepsilon, \%$ \\
\hline$-2.5+1.6$ & 21.91 & 5.79 & 48.39 & 31.25 & 1.37 & 31.3 & 36.1 & 0.31 & 21.01 \\
\hline$-1.6+0.25$ & 56.68 & 2.13 & 46.33 & 52 & 0.89 & 34.5 & 22.7 & 0.45 & 19.26 \\
\hline-0.25 & 21.41 & 0.64 & 5.28 & 15.94 & 2.92 & 34.2 & 41.2 & 0.77 & 59.83 \\
\hline $\begin{array}{c}\beta \text { in a } \\
\text { sample, } \%\end{array}$ & & 2.6 & & & 1.36 & & & 0.53 & \\
\hline
\end{tabular}

The data support significant dependence of copper content upon the sample size. Ten technological samples were analyzed to identify distribution nature of native copper in the context of different grades of the crushed rock. Figure 3, a represents graphically a sieve analysis (in terms of size); Figure $3 b$ explains copper content distribution within the size grades of the crushes.

According to the results, copper content corresponds to the standards of ore mined industrially (i.e. more than $0.35 \%$ ) in each narrow lava-breccia size grade. The abovementioned concerns even the thinnest grades. In the context of lavabreccia, copper content in small grades $(-1.0 \mathrm{~mm})$ is lower to compare with the larger ones $(+1.0 \mathrm{~mm})$. As for the large grades (-10-1.0 mm), copper distribution is almost uniform.

The available experimental data of processing crushing indices have made it possible to obtain analytical dependences of distribution of technological parameters in terms of crushing product size. In this context, arithmetic mean value of its boundary values was considered as a size characteristic for each specific grade. As a result, parabolic dependence was derived to distribute a yield of the crushed rock mass according to its largeness. The dependence is as follows:

$$
\gamma=0.47 x^{2}-11.77 x+92.08, R^{2}=0.955
$$

where:

$$
\gamma \text { - a size yield, } \%
$$

$x-$ a largeness, $\mathrm{mm}$.

Coefficient is $R^{2}=0.955$ supporting high adequacy level of the model. In terms of size, copper content is described using following dependence:

$$
\beta=0.168 \ln (x)+0.928, R^{2}=0.833,
$$

where:

$$
\begin{aligned}
& \beta \text { - a copper content; } \\
& x \text { - a largeness, mm. }
\end{aligned}
$$


(a)

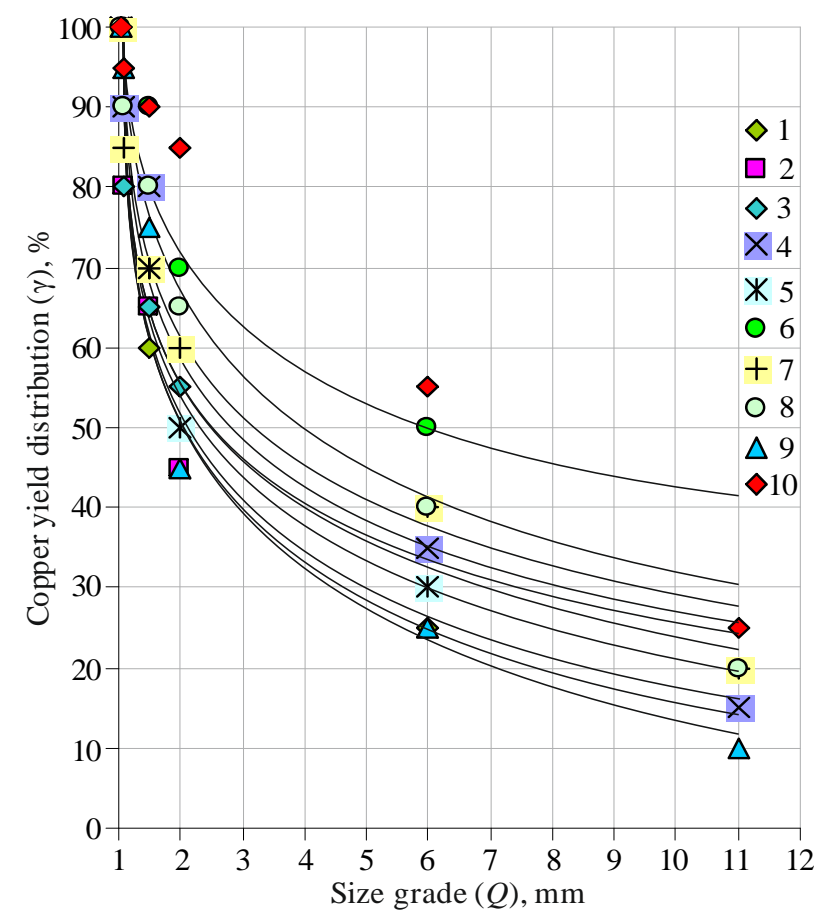

(b)

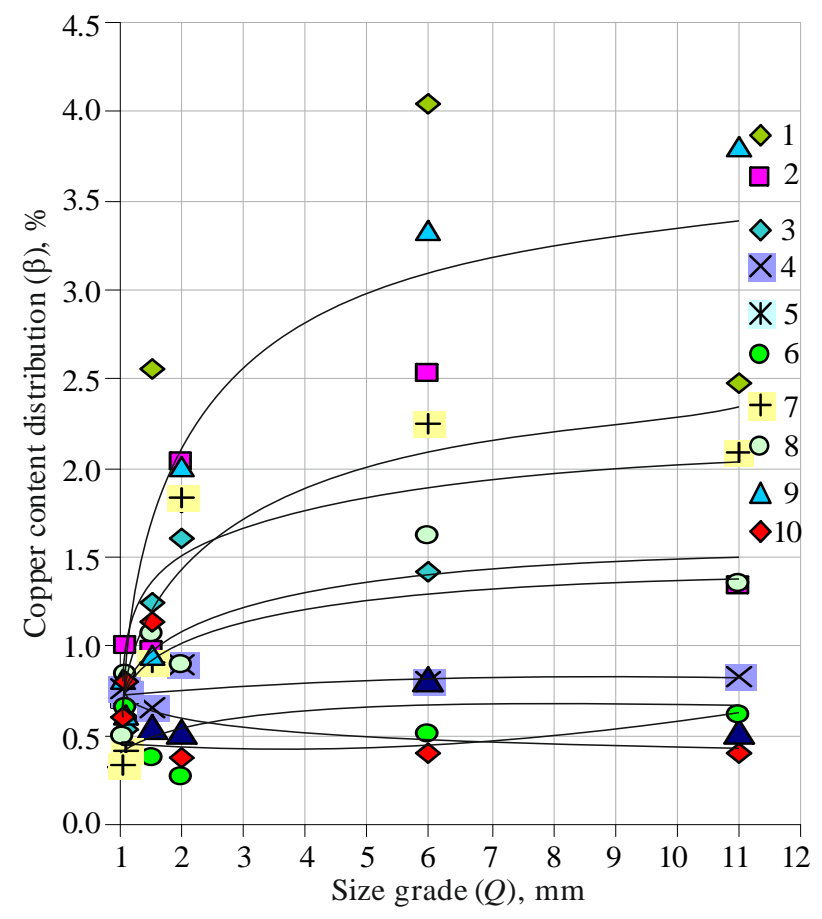

Figure 3. Size grade distribution of crushes: (a) cumulative characteristics of copper yield distribution; (b) cumulative characteristics of copper content distribution

Relatively small $R^{2}$ value depends upon the copper content dispersion within large $-10+2.5 \mathrm{~mm}$ grades. Large lavabreccia $-10+1.0 \mathrm{~mm}$ grades are the richest in copper denoting the possibility to apply preconcentration; for instance, it may be performed using electric separators by Ganson's Sorters (Great Britain), Ore Sorter (USA) etc.

The second order polynomial describes copper extraction (ع) distribution:

$\varepsilon=-0.06 x^{2}-11.77 x+92.08, R^{2}=0.96$.
The significant value of coefficient of determination (i.e. $\left.R^{2}=0.96\right)$ supports high degree of adequacy of the model.

The (1)-(3) dependences concerning distribution of rock yield as well as copper content and extraction in terms of grades have been derived for the first time. They may be applied for prediction calculations while developing a complex ore preparation method. According to the obtained experimental data (Table 2 and 3), the authors have identified analytical dependences of granulometric composition of tuff produced in an open pit and in a well. Following dependence is the most suitable for unfragmented and fragmented tuff:

$Q_{k}=\frac{A}{K}+B$,

where:

$K$ - a largeness value, $\%$;

$A$ and $B$ - the variable experimental coefficients.

Hyperbolic nature of the tabular data can be explained by their variation since insignificant percentage size $K(\%)$ values factor into the drastic decrease in $Q_{k}$ largeness value; if largeness value $K$ increases, then size values experience less increase (Table 2 and 3). Hence, the regression model has been obtained for the unfragmented tuff:

$Q_{k n}=\frac{304.98}{K}+61.02$

where determination coefficient is $r^{2}=0.904$.

In the context of the fragmented tuff, the model is as follows:

$Q_{k n}=\frac{1901.66}{K}-0.665$,

where determination coefficient is $r^{2}=0.981$.

The determination coefficients of both models denote their adequacy as for the description of the identified experimental dependences. In the process of tuff fragmentation using a roll crusher, the end product size depends upon spacings between rolls as well as upon the tuff fragmentation condition. The dependences are represented experimentally in Figure 1 and 2. The dependences have been visualized for such spacings of roll crusher as $\Delta=3,6$, and $10 \mathrm{~mm}$. Since the experimental graphs are represented separately for the spacings, individual regression model has been developed for each spacing between rollers. The models were calculated as dual regressions of $\gamma=a+b K$ type.

The calculation results for the unfragmented tuff are as follows:

$$
\begin{aligned}
& -\gamma_{n}=-0.188+0.0199 K_{n} \text { for } \Delta=3 \mathrm{~mm} \text { if } r^{2}=0.975 \\
& -\gamma_{n}=-0.3147+0.0441 K_{n} \text { for } \Delta=6 \mathrm{~mm} \text { if } r^{2}=0.997 \\
& -\gamma_{n}=-0.2068+0.0653 K_{n} \text { for } \Delta=10 \mathrm{~mm} \text { if } r^{2}=0.956
\end{aligned}
$$

Determination coefficients are high for the models. The abovementioned supports adequacy of the obtained linear models to the experimental data. Figure 4 compares experimental and analytical graphs confirming their acceptable similarity.

A model for the fragmented tuff was selected similarly to the abovementioned. Following models were obtained for the assumed roll crusher spacings:

$$
\begin{aligned}
& -\gamma_{p}=-0.0154+0.0127 K_{p} \text { for } \Delta=3 \mathrm{~mm} \text { if } r^{2}=0.951 \\
& -\gamma_{p}=-0.0832+0.0247 K_{p} \text { for } \Delta=6 \mathrm{~mm} \text { if } r^{2}=0.984 \\
& -\gamma_{p}=-0.4106+0.0545 K_{p} \text { for } \Delta=10 \mathrm{~mm} \text { if } r^{2}=0.998
\end{aligned}
$$




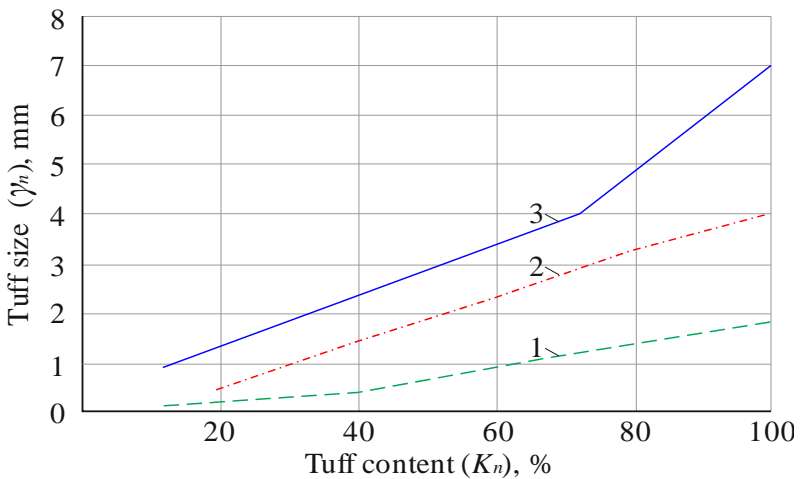

Figure 4. Comparative evaluation of experimental dependence of crushing degree and analytical one for the unfragmented tuff: $1-3 \mathrm{~mm} ; 2-6 \mathrm{~mm} ; 3-10 \mathrm{~mm}$

In this context, the authors also obtained high determination coefficients for the models supporting their high adequacy. Figure 5 demonstrates mutually agreed actual and analytical dependences.

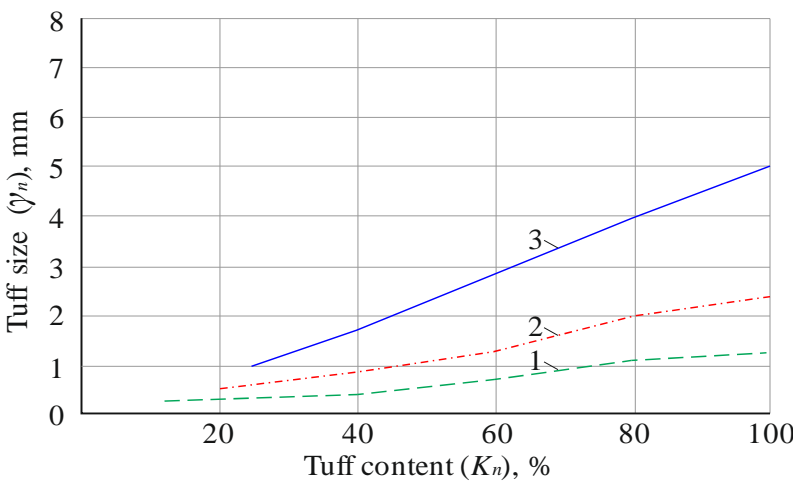

Figure 5. Comparative evaluation of the experimental and analytical dependences of crushing degree for the unfragmented tuff: $1-3 \mathrm{~mm} ; 2-6 \mathrm{~mm} ; 3-10 \mathrm{~mm}$

Taking into consideration the necessity to crush basalt mass and grind as well as availability of fine native copper inclusions, it is expedient to apply a roller crusher after a jaw breaker since the former can operate in a grinding mode while decreasing a gap between rollers $\left(\Delta_{p}, \mathrm{~mm}\right)$. The development of a method for ore preparation of basalt raw materials involves the necessity to identify a degree of influence of various factors on the roller crusher efficiency for subsequent modeling of the process and prediction of its parameters. Hence, effect of following factors has been determined experimentally: roller diameter $(D, \mathrm{~mm})$; size of a lump being loaded into a crusher $(\rho, \mathrm{mm})$; roller length $(L, \mathrm{~mm})$; roll spacing size $\left(\Delta_{\rho}, \mathrm{mm}\right)$; density of the crushed material $\left(\gamma, \mathrm{kg} / \mathrm{m}^{3}\right): \quad \gamma=1.4 \mathrm{~kg} / \mathrm{m}^{3}$ for tuff; $\gamma=2.2 \mathrm{~kg} / \mathrm{m}^{3}$ for lavabreccia; $\gamma=2.4-2.6 \mathrm{~kg} / \mathrm{m}^{3}$ for basalt; $\gamma=4.0 \mathrm{~kg} / \mathrm{m}^{3}$ for titanomagnetite inclusions; and for roller rotation frequency $(\omega, \mathrm{rpm})$. Dependences of roller crusher efficiency upon the listed factors have been derived; they have been represented graphically; and following generalized regression models have been used to determine its efficiency for all rocks of basalt raw materials:

$Q_{t}=2.167-0.00086 \omega^{2}-0.00089 \rho^{2}-0.000024 D^{2}+$ $+0.000062 L D+0.0263 \omega \Delta_{\rho}+0.0007 \omega D$,
$R^{2}=0.981 ; F=183.1$ for tuff;

$Q_{l-b}=1.741-0.00078 \omega^{2}-0.00083 \rho^{2}-0.024 \Delta^{2}-$

$-0.000057 L D+0.0032 \omega \Delta+0.00052 \omega D$,

$R^{2}=0.9791 ; F=134.5$ for lava-breccia;

$Q_{b}=3.27-0.085 \rho-0.0007 \omega^{2}-0.000022 D^{2}+$

$+0.00005 L D+0.021 \omega \Delta+0.00057 \omega D$,

$R^{2}=0.976 ; F=132.3$ for basalt.

For titanium-magnetite agglomerations:

$Q_{t-m}=1.62-0.066 \rho-0.0066 \omega^{2}-0.026 \Delta^{2}-$

$-0.000013 D^{2}+0.00004 L D+0.029 \omega \Delta+0.0004 \omega D$,

$R^{2}=0.982 ; F=188.4$.

Roller crusher efficiency $\left(G_{\omega}\right)$ depends heavily upon unloading opening size $\Delta$; that is why dependence of yield of six specific $\mathrm{k}$ grades was determined for such opening sizes as $\Delta=30 \mathrm{~mm} ; \Delta=20 \mathrm{~mm}$; and $\Delta=10 \mathrm{~mm}$.

Tuff with $\gamma=1.6$ density and $80-100$ size is supplied to a roller crusher where opening size is controlled. The abovementioned stipulates correspondent distribution of the material being crushed by size at the breaker exit as well as its efficiency. Table 6 explains tuff distribution in terms of sizes after the use of a roller crusher.

Table 6. Tuff distribution in terms of sizes after crushing

\begin{tabular}{ccccc}
\hline & & \multicolumn{3}{c}{ The size content in the crushed product, \% } \\
\cline { 3 - 5 }$\#$ & Size, mm & $\begin{array}{c}30 \mathrm{~mm} \\
\text { opening }\end{array}$ & $\begin{array}{c}20 \mathrm{~mm} \\
\text { opening }\end{array}$ & $\begin{array}{c}10 \mathrm{~mm} \\
\text { opening }\end{array}$ \\
\hline 1 & $-30.0+20.0$ & 41.0 & - & - \\
2 & $-20.0+10.0$ & 28.0 & 50.0 & - \\
3 & $-10.0+5.0$ & 16.0 & 30.0 & 58.0 \\
4 & $-5.0+3.0$ & 6.0 & 8.0 & 26.0 \\
5 & $-3.0+1.0$ & 5.0 & 7.0 & 10.0 \\
6 & $-1.0+0.5$ & 3.0 & 5.0 & 6.0 \\
$G$ & - & $100 \%=10 \mathrm{t} / \mathrm{y}$ & $100 \%=7.5 \mathrm{t} / \mathrm{y}$ & $100 \%=4.5 \mathrm{t} / \mathrm{y}$ \\
\hline
\end{tabular}

As a result, statistic models have been obtained. The models identify the correlation of $G$ yield according to six specific $k$ grades in terms of different opening sizes:

$G=0.475+2.09 k-0.018 k^{2}$,

for $\Delta=30 \mathrm{~mm} ; R^{2}=0.993$;

$G=0.011+3.51 k-0.09 k^{2}$

for $\Delta=20 \mathrm{~mm} ; R^{2}=0.962$;

$G=2.12+3.74 k-0.5 k^{2}$,

for $\Delta=10 \mathrm{~mm} ; R^{2}=0.997$.

Along with the decrease in the opening of a jaw breaker, yield of large grades decreases, factoring into the decreased dispersed size as well as into the improved conditions of further processing of the basalt by means of a roller crusher. However, the abovementioned extends the period required to obtain the final product. In this context, loss in jaw breaker efficiency takes place. Thus, a dependence of jaw breaker efficiency $Q$ upon the unloading spacing dimensions has been derived, if lumps to be supplied are $10-90 \mathrm{~mm}$ in size as well as analytical model in the form of a linear dependence: 
$Q=1.17+0.3 \Delta$,

where $\Delta=10 \mathrm{~mm} ; 20 \mathrm{~mm}$; and $30 \mathrm{~mm}$.

The research has made it possible to obtain dependences of distribution of technological parameters (i.e. product yield; and copper content and yield) in terms of sizes. Moreover, the basic factors for crushing process have been identified; and regression dependences of crusher efficiency upon output factors have been derived. In addition, regression model of general technological ore preparation schedule has been obtained involving crushing by means of jaw breaker, and grinding by means of a roller one. The abovementioned helps evaluate efficiency of a test area to process basalt raw material at a stage of design and operation as well as identify the required parameters of the crushing and grinding facilities.

Hence, the research has shown that tuff is valuable raw material being of interest to industry since the mineral contains precious components in the form of native copper, iron, and titanium. Extraction of the components is both feasible technologically and expedient economically. According to the data by geological studies, reserves of tuff raw materials within Rivne-Volyn territory make it possible to perform their long-term mining. Moreover, tuff derivative products may be used widely in Ukraine.

\section{Conclusions}

The research has determined that in percentage terms, distribution of granulometric composition while crushing tuff produced from open pits and wells subjects to a hyperbolic law; in addition, it is simulated using a regression model pretty exactly.

Intensive tuff moistening results in its fragmentation; the final crushing and grinding product size depends exponentially upon spacing between mill rolls being simulated in the form of a dual regression model.

The research has helped identify empiric mathematical models making it possible to predict changes in granulometric tuff composition while crushing and grinding. The findings may be applied while designing tuff processing lines and obtaining valuable mineral components from it.

\section{Acknowledgements}

The research was carried out hosted by the National University of Water and Environmental Engineering (NUWEE, city of Rivne) and with the participation of experts from Rafalivsky karier PJSC (Village of Ivanchi, Volodymyrets District, Rivne Region). The authors show their gratitude to the NUWEE authorities for the opportunity to carry out the study using laboratory facilities of the University, and to the authorities of Rafalivsky karier PJSC represented by its Director P.P. Bortnyk for the chance to analyze deep tuff as well as tuff within the dumps of Rafalivka open pit.

\section{References}

[1] Malanchuk, Z.R., Moshynskyi, V.S., Korniienko, V.Y., Malanchuk, Y.Z., \& Lozynskyi, V.H. (2019). Obgruntuvannia parametriv rozmyvu y peretikannia pulpy tseolit-smektytovoho tufu u vydobuvnii kameri. Naukovyi Visnyk NHU, (6), 11-18.

[2] Malanchuk, Z., Malanchuk, Y., Korniyenko, V., \& Ignatyuk, I. (2017). Examining features of the process of heavy metals distribution in technogenic placers at hydraulic mining. Eastern-European Journal of En- terprise Technologies, 1(10(85)), 45-51. https://doi.org/10.15587/17294061.2017.92638

[3] Moshynskyi, V., Malanchuk, Z., Tsymbaliuk, V., Malanchuk, L., Zhomyruk, R., \& Vasylchuk, O. (2020). Research into the process of storage and recycling technogenic phosphogypsum placers. Mining of Mineral Deposits, 14(2), 95-102. https://doi.org/10.33271/mining14.02.095

[4] Burdeniuk, I.P., Kovbasa, I.M., Voloshchuk, A.H., Petriuk, A.Ye., \& Pastushenko, Ye.P. (2013). Pryrodnyi mineral - bazaltovyi tuf, perspektyvy zastosuvannia $\mathrm{v}$ kharchovii promyslovosti, biolohii ta medytsyni. Klinichna ta Eksperymentalna Patolohiia, 12(2), 35-41.

[5] Sandeep, C.S., Todisco, M.C., Nardelli, V., Senetakis, K., Coop, M.R., \& Lourenco, S.D.N. (2018). A micromechanical experimental study of highly/completely decomposed tuff granules. Acta Geotechnica, 13(6), 1355-136. https://doi.org/10.1007/s11440-018-0656-3

[6] Heiken, G. (2006). Tuffs - Their properties, uses, hydrology, and resources. Geological Society of America. https://doi.org/10.1130/08137-2408-2.1

[7] Smorodinova, T.N., \& Kotvanova, M.K. (2016). Regional zeolitic tuffs as effective additions to cements. Yugra State University Bulletin, 12(3), 20-25. https://doi.org/10.17816/byusu201612320-25

[8] Dychkovskyi, R., Vladyko, O., Maltsev, D., \& Cabana, E.C. (2018). Some aspects of the compatibility of mineral mining technologies. Rudarsko-Geološko-Naftni Zbornik, 33(4), 73-82. https://doi.org/10.17794/rgn.2018.4.7

[9] Lozynskyi, V., Saik, P., Petlovanyi, M., Sai, K., Malanchuk, Z. \& Malanchuk, Y. (2018). Substantiation into mass and heat balance for underground coal gasification in faulting zones. Inzynieria Mineralna, 19(2), 289-300. https://doi.org/10.29227/IM-2018-02-36

[10] Bazaluk, O., Petlovanyi, M., Lozynskyi, V., Zubko, S., Sai, K., \& Saik, P. (2021). Sustainable Underground Iron Ore Mining in Ukraine with Backfilling Worked-Out Area. Sustainability, 13(2), 834. https://doi.org/10.3390/su13020834

[11] Stupnik, N., Kalinichenko, V., Kolosov, V., Pismennyy, S., \& Shepel, A. (2014). Modeling of stopes in soft ores during ore mining. Metallurgical and Mining Industry, 6(3), 32-37.

[12] Török, Á., Barsi, Á., Bögöly, G., Lovas, T., Somogyi, Á., \& Görög, P. (2018). Slope stability and rockfall assessment of volcanic tuffs using RPAS with 2-D FEM slope modelling. Natural Hazards and Earth System Sciences, 18(2), 583-597. https://doi.org/10.5194/nhess-18-583-2018

[13] Stupnik, M.I., Kalinichenko, V.O., Kalinichenko, O.V., Muzika, I.O., Fed'ko, M.B., \& Pis'menniy, S.V. (2015). The research of strain-stress state of magnetite quartzite deposit massif in the condition of mine "Gigant-Gliboka" of central iron ore enrichment works (CGOK). Metallurgical and Mining Industry, (7), 377-382.

[14] Mambetov, S.A., Mambetov, A.S., \& Abdiev, A.R. (2002). Zonal and step-by-step evaluation of the stressed-strained state of Tyan-Shan' rock massif. Gornyi Zhurnal, (10), 57-62.

[15] Song, Y., Wang, H., \& Ren, M. (2019). Experimental study on deformation and failure characteristics of discontinuous prefabricated fractured tuff. Journal of Geophysics and Engineering, 16(5), 862-874. https://doi.org/10.1093/jge/gxz052

[16] Stupnik, M., Kalinichenko, V., \& Pismennyi, S. (2013). Pillars sizing at magnetite quartzites room-work. Annual Scientific-Technical Collection - Mining of Mineral Deposits, 11-15. https://doi.org/10.1201/b16354-3

[17] Malanchuk, Z., Moshynskyi, V., Stets, S., Martyniuk, P., \& Galiyev, D. (2020). Modelling hydraulic mixture movement along the extraction chamber bottom in case of hydraulic washout of the puff-stone. E3S Web of Conference, (201), 01011. https://doi.org/10.1051/e3sconf/202020101011

[18] Buzylo, V., Pavlychenko, A., Savelieva, T., \& Borysovska, O. (2018). Ecological aspects of managing the stressed-deformed state of the mountain massif during the development of multiple coal layers. E3S Web of Conferences, (60), 00013. https://doi.org/10.1051/e3sconf/20186000013

[19] Popovych, V., Stepova, K., \& Prydatko, O. (2018). Environmental hazard of Novoyavorivsk municipal landfill. MATEC Web of Conferences, (247), 00025. https://doi.org/10.1051/matecconf/201824700025

[20] Popovych, V., Telak, J., Telak, O., Malovanyy, M., Yakovchuk, R., \& Popovych, N. (2020). Migration of hazardous components of municipal landfill leachates into the environment. Journal of Ecological Engineering, 21(1), 52-62. https://doi.org/10.12911/22998993/113246

[21] Lyashenko, V. (2018). Safety improving of mine preparation works at the ore mines. Bezopasnost' Truda v Promyshlennosti, (5), 53-59. https://doi:10.24000/0409-2961-2018-5-53-59

[22] Malanchuk, Z., Moshynskyi, V., Malanchuk, V., Korniienko, Y., \& Koziar, M. (2020). Results of research into the content of rare earth materials in man-made phosphogypsum deposits. Key Engineering Materials, (844), 77-87. https://doi.org/10.4028/www.scientific.net/kem.844.77

[23] Goswami, S., Upadhyay, P.K., Bhagat, S., Zakaulla, S., Bhatt, A.K., Natarajan, V., \& Dey, S. (2018). An approach of understanding acid volcanics and tuffaceous volcaniclastics from field studies: A case 
from Tadpatri Formation, Proterozoic Cuddapah basin, Andhra Pradesh, India. Journal of Earth System Science, 127(2), 20 https://doi.org/10.1007/s12040-018-0929-0

[24] Pivnyak, G., Dychkovskyi, R., Cabana, E.C, Lozynskyi, V., \& Saik, P (2020). Actual challenges in materials science and processing technologies. Preface. Key Engineering Materials, (844), 4

[25] Pötzl, C., Siegesmund, S., Dohrmann, R., Koning, J.M., \& Wedekind, W. (2018). Deterioration of volcanic tuff rocks from Armenia: Constraints on salt crystallization and hydric expansion. Environmental Earth Sciences 77(19), 660. https://doi.org/10.1007/s12665-018-7777-8

[26] Arslanov, M.Z., Mustafin, S.A., Zeinullin, A.A., Kulpeshov, B.S., \& Mustafin, T.S. (2020). Model for determining classification of filling materials hardening. News of National Academy of Sciences of the Republic of Kazakhstan, 5(443), 6-12. https://doi.org/10.32014/2020.2518-170x.98

[27] Malanchuk, Y., Korniienko, V., Malanchuk, L., \& Zaiets, V. (2020). Research into the moisture influence on the physical-chemical tuff-stone characteristics in basalt quarries of the Rivne-Volyn region. E3S Web of Conferences, (201), 01036. https://doi.org/10.1051/e3sconf/202020101036

[28] Malanchuk, Ye. (2014). Efficiency determination of using magnetic separation while processing of basalt raw material. Progressive Technologies of Coal, Coalbed Methane, and Ores Mining, 83-86. https://doi.org/10.1201/b17547-14

[29] Tsymbaliuk, V.V., Voloshchuk, A.H., \& Kobasa, I.M. (2009). Vplyv termichnoi obrobky na sorbtsiini vlastyvosti bazaltovoho. Ukrainskyi Khimichnyi Zhurnal, (75), 85-90.

[30] Tsymbaliuk, V.V., Voloshchuk, A.H., \& Kobasa, I.M. (2009). Vplyv khimiko-termichnoho modyfikuvannia na fizyko-khimichni vlastyvosti bazaltovoho tufu. Naukovyi Visnyk Chernivetskoho Universytetu. Seriia: Khimiia, (453), 63-68.

[31] Malanchuk, Z., Moshynskyi, V., Malanchuk, Y., \& Korniienko, V. (2018). Physico-mechanical and chemical characteristics of amber. Solid State Phenomena, 80-89. https://doi.org/10.4028/www.scientific.net/ssp.277.80

[32] Ghobadi, M.H., Taleb Beydokhti, A.R., Nikudel, M.R., Asiabanha, A. \& Karakus, M. (2016). The effect of freeze-thaw process on the physical and mechanical properties of tuff. Environmental Earth Sciences 75(9), 846. https://doi.org/10.1007/s12665-016-5664-8

[33] Mulyavko, V.I., Oleynik, T.A., Oleynik, M.O., Mikhno, S.V., \& Lyashenko, V.I. (2014). Innovation technologies and machinery for separation of feebly magnetic ores. Obogashchenie Rud, (2), 43-49.

[34] Menshov, O., Kruglov, O., Vyzhva, S., Nazarok, P., Pereira, P., \& Pastushenko, T. (2018). Magnetic methods in tracing soil erosion, Kharkov Region, Ukraine. Studia Geophysica et Geodaetica, 62(4), 681-696. https://doi.org/10.1007/s11200-018-0803-1

[35] Menshov, O., Sukhorada, A., Homenko, R., \& Kruglov, O. (2012) Ultradetailed environmental magnetic investigations in Ukraine. Near Surface Geoscience $2012-18^{\text {th }}$ European Meeting of Environmental and Engineering Geophysics, cp-306-00099. https://doi.org/10.3997/2214 4609.20143416

[36] Asniar, N., Purwana, Y.M., \& Surjandari, N.S. (2019). Tuff as rock and soil: Review of the literature on tuff geotechnical, chemical and mineralogical properties around the world and in Indonesia. Exploring Resources, Process and Design for Sustainable Urban Development: Engineering, Technology, and Industrial Application, (2114), 050022 https://doi.org/10.1063/1.5112466

[37] Kleb, B., \& Vásárhelyi, B. (2003). Test results and empirical formulas of rock mechanical parameters of rhiolitic tuff samples from Eger's cellars. Acta Geologica Hungarica, (46), 301-312. https://doi.org/10.1556/AGeol.46.2003.3.5

\section{Закономірності розподілу гранулометричного складу туфу в процесі дроблення}

\section{Є. Маланчук, В. Мошинський, П. Денисюк, З. Маланчук, А. Христюк, В. Корнієнко, П. Мартинюк}

Мета. Аналіз розподілу гранулометричного та елементного складу туфів і визначення залежності їх розущільнення при насиченні водою на основі комплексу експериментальних досліджень для оцінки їх мінерально-сировинної цінності.

Методика. Експериментальним шляхом у лабораторних умовах було встановлено елементний склад туфів 3 різних кар'єрів регіону. 3 використанням методів математичної статистики отримано аналітичні залежності, що описують розміцнення туфів при насиченні їх водою, які вказують на логарифмічний характер збільшення насичення при збільшенні маси зразка.

Результати. Встановлено, що туфи є не відходами видобутку базальтів, а цінною мінеральною сировиною, яка потребує розробки та комплексних підходів до переробки й вилучення корисних металів і силікатів. Встановлені аналітичні залежності розміцнення туфів при насиченні водою, якіа вказують на логарифмічний характер збільшення насичення при збільшення маси зразка. Встановлено магнітну сприйнятливість туфів, що залежить від індукції магнітного поля. Виявлені залежності розподілу технологічних показників (вихід продукту, вміст і вихід міді) за класами крупності, визначені основні фактори для процесу дроблення й отримані регресійні залежності продуктивності дробарки від вихідних факторів. Отримано регресійну модель процесу дроблення загальної технологічної схеми рудопідготовки, що включає первинне дроблення в щоковій дробарці та додроблення (здрібнювання) у валковій. 
Наукова новизна. Встановлено, що магніточутлива частина туфів становить $49 \%$ від маси проби, а решта - силікатна частина. Встановлено логарифмічний характер аналітичних залежностей розміцнення при насиченні водою, що вказує на збільшення насичення при збільшенні маси зразка.

Практична значимість. Визначення елементного складу туфів та аналітичних залежностей розміцнення при насиченні водою дозволяє проводити розрахунок необхідних витрат води.

Ключові слова: туфи, базальт, розмічнення, водонасичення, силікати, магніточутливість, елементний склад, дроблення

\section{Закономерности распределения гранулометрического состава туфа в процессе дробления}

\section{Е. Маланчук, В. Мошынский, П. Денисюк, З. Маланчук, А. Христюк, В. Корниенко, П. Мартынюк}

Цель. Анализ распределения гранулометрического и элементного состава туфа и определение зависимости их разуплотнения при насыщении водой на основе комплекса экспериментальных исследований для оценки их минерально-сырьевой ценности.

Методика. Экспериментальным путем в лабораторных условиях было установлено элементный состав туфов из различных карьеров региона. С использованием методов математической статистики получены аналитические зависимости, описывающие разуплотнение туфов при насыщении их водой, которые указывают на логарифмический характер увеличения насыщения при увеличении массы образца.

Результаты. Установлено, что туфы - это не отходы добычи базальтов, а ценное минеральное сырье, которое требует разработки и комплексных подходов к переработке и извлечению полезных металлов и силикатов. Установлены аналитические зависимости разуплотнения туфов при насыщении водой, указывающие на логарифмический характер увеличения насыщения при увеличении массы образца. Установлено магнитную восприимчивость туфов, которая зависит от индукции магнитного поля. Выявлены зависимости распределения технологических показателей (выход продукта, содержание и выход меди) по классам крупности, определены основные факторы для процесса дробления и получены регрессионные зависимости производительности дробилки от исходных факторов. Получена регрессионная модель процесса дробления общей технологической схемы рудоподготовки, включающей первичное дробление в щековой дробилке и додробление (измельчение) в валковой.

Научная новизна. Установлено, что магниточувствительная часть туфов составляет 49\% от массы пробы, а остальное - силикатная часть. Установлено логарифмический характер аналитических зависимостей разуплотнения при насыщении водой, что указывает на увеличение насыщения при увеличении массы образца.

Практическая значимость. Определение элементного состава туфов и аналитических зависимостей разуплотнения при насыщении водой позволяет производить расчет необходимых затрат воды.

Ключевые слова: туфы, базальт, разуплотнение, водонасыщение, силикат, магниточувствительность, элементный состав, дробление 